\title{
Simulation of soil carbon efflux from an arable soil using the ECOSSE model: Need for an improved model evaluation framework?
}

\author{
Padraig Flattery ${ }^{\mathrm{a}, *}$, Rowan Fealy ${ }^{\mathrm{b}}$, Reamonn M. Fealy ${ }^{\mathrm{c}}$, Gary Lanigan ${ }^{\mathrm{d}}$, Stuart Green ${ }^{\mathrm{c}}$ \\ a Irish Climate Analysis Research Units (ICARUS), Department of Geography, Maynooth University, Maynooth, Co. Kildare, Ireland \\ b Department of Geography, Maynooth University, Maynooth, Co. Kildare, Ireland \\ ' Teagasc, Rural Economy \&' Development Centre, Ashtown, Dublin. D15 KN3K, Ireland \\ d Teagasc, Johnstown Castle, Co. Wexford. Y35 Y521, Ireland
}

\section{H I G H L I G H T S}

- Soil carbon modelling is essential for quantification of GHG flux.

- Commonly used soil C model was evaluated and discrepancies were found.

- Deconstruction of model rate modifiers shows deficiency in water component.

- $\mathrm{r}^{2}$ Values improve significantly using observed soil water content instead of modelled.

- We recommend stronger evaluation of biogeochemical models.

\section{A R T I C L E I N F O}

\section{Article history:}

Received 27 October 2017

Received in revised form 5 December 2017

Accepted 7 December 2017

Available online 13 December 2017

Editor: Ouyang Wei

\section{Keywords:}

$\mathrm{CO}_{2}$ flux

Biogeochemical modelling

Soil water

ECOSSE

\section{GRAPHICALABSTRACT}

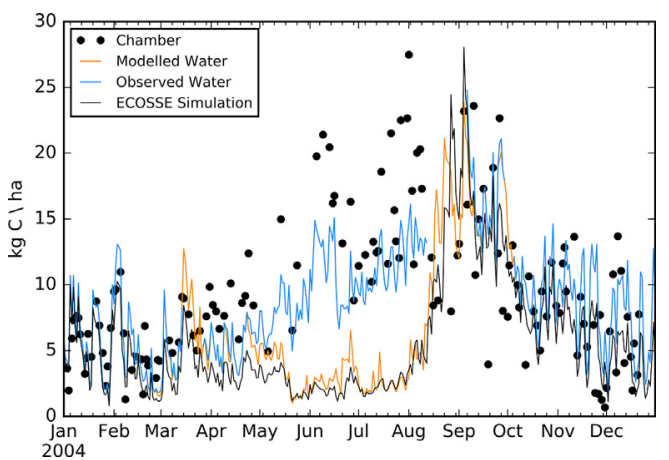

\begin{abstract}
A B S T R A C T
Globally, it is estimated that $\sim 1500 \mathrm{Pg}$ C of organic carbon is stored in the top meter of terrestrial soils. This represents the largest terrestrial pool of carbon. Appropriate management of soils, to maintain or increase the soil carbon pool, represents a significant climate change mitigation opportunity. To achieve this, appropriate tools and models are required in order to more accurately estimate soil carbon fluxes with a view to informing and developing more effective land use management strategies. Central to this is the evaluation of models currently in use to estimate soil carbon emissions. In the present study, we evaluate the ECOSSE (Estimating Carbon in Organic Soils - Sequestration and Emissions) model which has its origins in both SUNDIAL and RothC and has been widely used globally to model soil $\mathrm{CO}_{2}$ fluxes across different locations and land-use types on both organic and mineral soils. In contrast to previous studies, the model was found to poorly represent observed soil respiration at the study site, an arable cropland on mineral soil located in south-east Ireland. To isolate potential sources of error, the model was decomposed into its component rate equations or modifiers. This investigation highlighted a deficiency in the model simulated soil water, resulting in significant inhibition of the model simulated $\mathrm{CO}_{2}$ flux relative to the observed data. When measured values of soil water at the site were employed, the model simulated soil respiration improved significantly ( $\mathrm{r}^{2}$ of 0.775 vs 0.154 ). This highlighted model deficiency remains to be evaluated at other sites; however, the research highlights the need for a more comprehensive evaluation of soil carbon models prior to their use in informing policy, particularly models which are employed at larger scales and for climate change projections.
\end{abstract}

(c) 2017 Elsevier B.V. All rights reserved.

\footnotetext{
* Corresponding author at: Room 1.8 Laraghbryan House, Maynooth University, Maynooth, Co. Kildare, Ireland.

E-mail address: Padraig.flattery@mu.ie (P. Flattery).
} 


\section{Introduction}

Carbon emissions associated with land use, land use change and forestry (LULUCF) contribute the second largest source of carbon emissions to the atmosphere (Bond-Lamberty and Thomson, 2010; Scharlemann et al., 2014), with an estimated contribution of approximately $33 \%$ of total anthropogenic emissions, or $\sim 150$ petagrams carbon (Pg C; $10^{15} \mathrm{~g}$ ), over the period $1850-2000$ (Houghton, 2003). While the relative contribution has declined over recent decades (contributed $\sim 12.5 \%$ of total anthropogenic emissions between 1990 and 2010 - Houghton et al., 2012), largely attributed to an increase in fossil fuel emissions, increasing attention is being focused on simulating terrestrial carbon stocks and emissions, as terrestrial soils may present a significant climate change mitigation opportunity if managed appropriately.

Globally, it is estimated that approximately $1500 \mathrm{Pg}$ C of organic carbon is stored in uppermost meter of terrestrial soils (Scharlemann et al., 2014; Oertel et al., 2016). This represents the largest terrestrial carbon pool, roughly equivalent in sum to both the atmospheric (816 Pg C) and terrestrial phytomass (469.6 Pg C) pools (Scharlemann et al., 2014). Although estimates of SOC stocks in, and emissions from, terrestrial soils remain highly uncertain (Houghton et al., 2012; Scharlemann et al., 2014; Oertel et al., 2016), there remains a pressing need to improve our understanding of soil carbon management in order to minimise soil carbon losses and increase the carbon sequestration potential of soils (Scharlemann et al., 2014).

Soil $\mathrm{CO}_{2}$ efflux, or soil respiration $\left(\mathrm{R}_{\mathrm{S}}\right)$, is comprised of both heterotrophic $\left(R_{h}\right)$ (anaerobic and aerobic microbial decomposition) and autotrophic $\left(\mathrm{R}_{\mathrm{a}}\right)$ (plant root) respiration of $\mathrm{CO}_{2}$ from the soil to the atmosphere. While fine roots of woody plants can host heterotrophs (e.g. ectomycorrhizal fungi), the received nutrients are derived from photosynthesis and therefore generally considered in the autotrophic component (Högberg et al., 2005). The contribution of root respiration to total soil respiration is however highly variable, with published estimates ranging from $10 \%$ to $>90 \%$ depending on vegetation cover and season (Hanson et al., 2000), but on average is estimated to contribute up to $~ 50 \%$ of total soil respiration (Oertel et al., 2016). This partitioning varies between perennial and cropland systems as root growth commonly contributes an increased proportion to $\mathrm{R}_{\mathrm{s}}$ during the growing season (Hanson et al., 2000).

Ecosystem respiration ( $R_{\text {eco }}$, which includes both soil and aboveground plant respiration, also fluctuates seasonally with the growth cycle. The difference between carbon uptake by plants during photosynthesis and ecosystem respiration is referred to as the net ecosystem exchange (NEE). When the NEE is positive, the ecosystem represents a source of $\mathrm{CO}_{2}$ to the atmosphere and a $\mathrm{CO}_{2}$ sink when negative. As direct measurements of $R_{\text {eco }}$ and $R_{h}$ are difficult to obtain; $R_{h}$ is typically estimated from $R_{\text {eco }}$ which is in turn derived from NEE and GPP which are measured, or estimated from measured values, based on observations obtained at eddy covariance flux tower sites.

Soil respiration rates have been found to vary significantly with vegetation/plant type (Raich and Tufekciogul, 2000; Oertel et al., 2016). In general, a positive correlation is associated on an annual basis between soil respiration and above ground litter production (Raich and Schlesinger, 1992). Increasing vegetation cover also impacts on the soil microclimate, primarily associated with decreased soil temperatures due to increased leaf area and resultant shading effect (Oertel et al., 2016). A meta-analysis by Raich and Tufekciogul (2000) found on average that cropped fields displayed increased rates of soil respiration $(\sim 20 \%)$ relative to surrounding fields in fallow, however, this difference was not significant. Kessavalou et al. (1998) also found increased $\mathrm{CO}_{2}$ emissions during spring and summer, based on inter-row chamber measurements over arable cover (e.g wheat).

Belowground biomass, soil microbial activity and decomposition rates are highly dependent on soil temperature, soil water content, nutrient availability and soil pH (e.g. Singh and Gupta, 1977; Carlyle and Than, 1988; Raich and Schlesinger, 1992; Cook and Orchard, 2008; Guntiñas et al., 2013). As a result, soil respiration rates are predominantly influenced by meteorological, climatological and land management factors (e.g. land cover, land cover change, nutrient application etc. - Oertel et al., 2016). Process-based models, which seek to simulate soil carbon dynamics and/or soil respiration, therefore typically require these factors as input variables or parameters. For example, RothC (Rothamsted Carbon Model - Coleman and Jenkinson, 1996), requires information on soil type (e.g. proportion of clay) and inputs of meteorological variables (e.g. temperature, rainfall and potential evapotranspiration), plant residues and nutrient applications to simulate the turnover of organic carbon in topsoils. Similarly, ECOSSE (Estimating Carbon in Organic Soils - Sequestration and Emissions; Smith et al., 2010a), which has its origins in SUNDIAL (Simulation of Nitrogen Dynamics in Arable Land - Bradbury et al., 1993) and RothC (Coleman and Jenkinson, 1996), requires the specification of parameters such as soil $\mathrm{pH}$, bulk density, sand and silt content and soil depth, in addition to those parameters required by RothC, to simulate the soil fluxes of greenhouse gases (e.g. $\mathrm{CO}_{2}, \mathrm{~N}_{2} \mathrm{O}$, $\mathrm{CH}_{4}$ ) from organic soils. These models employ a common approach by partitioning soil organic matter (SOM) into 'pools' of inert organic matter (IOM), humus (HUM), biomass (BIO), resistant plant material (RPM) and decomposable plant material (DPM); processes and turnover rates of $C$ and $\mathrm{N}$ are then simulated using simple equations driven by common input variables such as soil characteristics and meteorological/climatological data. The decomposition process is described by first order rate equations (with specific rates for each pool) which are modified according to external factors such as temperature, moisture, crop cover and soil pH (Dondini et al., 2017).

The aim of this study was to evaluate the most recent version of the ECOSSE model (v6.2), in simulating observed soil respiration rates for croplands on a free-draining mineral soil. The study site used in this research was chosen as it contributed to FLUXNET, a network of regional networks of flux measurement sites; these sites record detailed information on the site characteristics (e.g. soil, meteorology etc.) necessary to run the model and, importantly, also had independent supplementary observations (NEE, soil chamber observations) which could be used to evaluate the model. The ECOSSE model was chosen for a number of reasons, (1) it has previously been applied at the study site to assess fluxes of greenhouse gases and SOC stock changes (Khalil et al., 2013) and was found to outperform other similar process-based models (e.g. DNDC, DailyDayCent) when estimating $\mathrm{N}_{2} \mathrm{O}$ fluxes (Khalil et al., 2016); (2) ECOSSE was developed from concepts initially implemented in SUNDIAL (Bradbury et al., 1993) and RothC (Coleman and Jenkinson, 1996) models which have been widely reported in the literature; (3) it has been applied widely in a variety of environments for different landuse types including European cropland (Smith et al., 2010b; Bell et al., 2011; Khalil et al., 2013; Dondini et al., 2017), peatland (Abdalla et al., 2014), land under Miscanthus and Willow (Dondini et al., 2016a) and bioenergy cover crops (Dondini et al., 2016b); and (4) ECOSSE can be scaled to derive national estimates of soil $\mathrm{C}$ with limited inputs, therefore the model could be employed to inform national inventories and policies. ECOSSE has also been coupled with JULES (Joint UK Land Environment Simulator), a community land surface model employed in the latest version of the UK Met Office Unified Model (Ostle et al., 2009).

Prior to undertaking the evaluation, the ECOSSE model was initialized using available measurements, or parameters and variables derived from observed values. Following this, the model was initially evaluated against $R_{h}$, derived as a proportion of $R_{\text {eco. }}$. However, due to concerns over the methods used to estimate $\mathrm{R}_{\mathrm{eco}}$, the model was subsequently evaluated against data obtained from a separate soil chamber experiment, results from which overlapped in time with the model simulations. Following this evaluation, soil respiration was then simulated using an alternative approach, which considered the individual contributions of the dominant external drivers of soil respiration, namely, temperature, moisture, crop cover and soil $\mathrm{pH}$, employing different formulations. 
The present research seeks to contribute to the existing, growing, literature on the evaluation of ECOSSE, but highlights a potential area for model improvement.

\section{Materials and methods}

\subsection{Soil respiration simulation}

The ECOSSE model and input requirements have been extensively described elsewhere (see Smith et al., 2010a; Dondini et al., 2016b; Dondini et al., 2017); only those details considered important for the current study are included here. Although ECOSSE was originally developed for organic soils, it has been widely applied and evaluated on mineral soils (Bell et al., 2011; Khalil et al., 2013; Dondini et al., 2016a; Dondini et al., 2016b; Dondini et al., 2017). In common with a number of similar models, ECOSSE describes the decomposition process using first order rate equations based on temperature, moisture, crop cover and soil $\mathrm{pH}$ (Dondini et al., 2017). These are outlined below; additional empirical formulations which relate the relevant variables to soil respiration are also outlined as they are subsequently employed.

\subsubsection{Soil temperature}

In the absence of soil moisture limitations, the relationship between soil respiration and temperature is generally considered to be positive, with colder soils inhibiting microbial activity and $\mathrm{CO}_{2}$ generation (Raich and Schlesinger, 1992; Lloyd and Taylor, 1994). However, the determination of the exact relationship remains challenging (Lloyd and Taylor, 1994). Consequently, a number of empirically based formulations, which relate soil respiration to either soil or air temperature, have been proposed. In this study a number of selected temperature modifiers (outlined below) were applied to the observed data to investigate the relevant ECOSSE modifier.

Based on analysis of data from a range of different ecosystems and soil temperatures, Lloyd and Taylor (1994) derived a simplified expression (Arrhenius type expression) for soil respiration rate based on temperature, at a standardized temperature of $10^{\circ} \mathrm{C}$ as follows,

$R_{S}=R_{10} \exp \left(308.56\left(\frac{1}{56.02}-\frac{1}{T-T_{0}}\right)\right)$

where, $R_{10}$ is the respiration rate at $10{ }^{\circ} \mathrm{C}$, T is air temperature and $\mathrm{T}_{0}$ is a temperature between T and $0 \mathrm{~K}$. Lloyd and Taylor (1994) suggest a value for $\mathrm{T}_{0}$ of $227.13 \mathrm{~K}$, which provided an optimized fit to the observational data employed in their analysis. Jacobs et al. (2007) provide an alternative formulation, originally developed for grasslands, again derived from a simple Arrhenius type expression and includes a correction to modify soil respiration for conditions of soil water stress, as follows,

$R_{S}=R_{10}(1-f(w)) \exp \left[\left(\frac{E_{0}}{283.15 R^{*}}\right)\left(1-\frac{283.15}{T_{\text {soil }}+273.15}\right)\right]$

Where, $f(w)=C \frac{w_{\max }}{w_{\text {soil }}+w_{\min }}$ where $\mathrm{E}_{0}$ is the activation energy $\left(\mathrm{kJ} \mathrm{kmol}^{-1}\right)$, $\mathrm{R}^{*}\left(\mathrm{~kJ} \mathrm{kmol}^{-1} \mathrm{~K}^{-1}\right)$ is the universal gas constant and $\mathrm{T}_{\text {soil }}$ is temperature in the first soil layer, and $\mathrm{f}(\mathrm{w})$ is a function to modify soil respiration under conditions of soil water stress, $\mathrm{w}_{\max }$ and $\mathrm{w}_{\min }$ are reference soil water content values of 0.55 and 0.005 , respectively.

The temperature function in ECOSSE is described as a first order process, following from SUNDIAL and RothC, for both anaerobic and aerobic decomposition, with $\mathrm{m}_{\mathrm{t}}$ the temperature rate modifier, specified as follows,

$m_{t}=\frac{47.9}{1+\exp \left(\frac{106}{T_{\text {air }}+18.27}\right)}$ where, $\mathrm{T}_{\text {air }}$ is the mean daily air temperature $\left({ }^{\circ} \mathrm{C}\right)$. ECOSSE assumes a $\mathrm{Q}_{10}$ constant (measure of the rate of change of a system as a consequence of $10{ }^{\circ} \mathrm{C}$ temperature increase) of 2.0 .

\subsubsection{Soil water}

There is a complex relationship between soil moisture and microbial respiration within soil (Reichstein and Beer, 2008); major factors affecting the rate of respiration include soil water content, substrate availability and time (Cook and Orchard, 2008) all of which vary with soil water content. Models typically simplify these interactions by using rate modifying factors. For example, the RothC model (Coleman and Jenkinson, 1996) which ECOSSE inherits some characteristics from, employs a modifying factor (b) for soil respiration due to soil moisture based on estimated soil moisture deficits (SMD), derived from rainfall and potential evapotranspiration (PE) data (Coleman and Jenkinson, 2014):

If accumulated (acc) $S M D<0.444 \max S M D$,

$\mathrm{b}=1$

Otherwise,

$b=0.2+(1.0-0.2) * \frac{\max S M D-a c c S M D}{\max S M D-0.444 \max S M D}$

Once a soil dries beyond a soil moisture deficit threshold, respiration becomes increasingly inhibited until wilting point, after which the modifier is set to 0.2. The ECOSSE water modifier has its origins in the SUNDIAL model (Bradbury et al., 1993; Smith et al., 1996) and assumes aerobic decomposition proceeds at maximum rate as the soil dries from field capacity to the amount of water held at $-100 \mathrm{kPa}$, decomposition is then increasingly inhibited until the soil reaches its permanent wilting point,

$m_{w}=1-\frac{\left(\left(1-m_{w 0}\right) x\left(\Psi_{f-} \Psi_{c-} \Psi_{i}\right)\right)}{\Psi_{f-} \Psi_{i}} ;\left(\right.$ if $\left.\left(\Psi_{f-} \Psi_{c}\right)<\Psi_{\mathrm{i}}, m_{w}=1\right)$

where, $m_{w 0}$ is the rate modifier at permanent wilting point $(0.2), \Psi_{\mathrm{c}}$ is the water held above permanent wilting point, $\Psi_{\mathrm{i}}$ is the water held between field capacity and $-100 \mathrm{kPa}$, and $\Psi_{\mathrm{f}}$ is the water held between field capacity and permanent wilting point (all units in $\mathrm{mm} /$ layer $^{-1}$ ). This is calculated for each $5 \mathrm{~cm}$ soil layer to the specified depth in ECOSSE; leaching between layers is by simple piston flow. Saturated conditions are also known to inhibit aerobic respiration (Reichstein and Beer, 2008) and ECOSSE includes a modifier for soil water conditions between field capacity and saturation. However, agricultural soils are considered to be free draining and as such, soil water rarely, if ever, exceeds field capacity.

\subsubsection{Vegetation cover}

The modifying effect of vegetation cover on soil respiration is simulated in ECOSSE using a crop modifier, originally derived from RothC. While the selection of the threshold is somewhat arbitrary, it is based on findings from a number of studies (e.g. Sommers et al., 1981; Sparling et al., 1982). The crop modifier ( $\mathrm{m}_{\mathrm{crop}}$ ) is set as.

$\mathrm{m}_{\text {crop }}=1$ if the soil is bare (no effect), and

$\mathrm{m}_{\text {crop }}=0.6$ if the soil is vegetated

The effect of which reduces soil respiration during the growing season by $40 \%$. 


\subsubsection{Soil $p H$}

The $\mathrm{pH}$ modifier in ECOSSE was introduced for organic soils where $\mathrm{pH}$ is more variable. The $\mathrm{pH}$ modifier is as follows,

$m_{p H}=m_{p H, \min }+\left(1-m_{p H, \min }\right)\left(\frac{p H-p H_{\min }}{p H_{\max }-p H_{\min }}\right)$

where aerobic decomposition proceeds at an optimum rate $\left(m_{p H}=1\right)$ until the pH falls below a critical threshold $\left(\mathrm{pH}_{\max }\right)$ and the minimum rate of decomposition is set as,

$m_{\mathrm{pH}, \min }=0.2, p H_{\min }=2, p H_{\max }=4.5$

\subsection{Site description}

The experimental site used in this study is an arable field located at the Teagasc Oak Park Research Centre, Co. Carlow, Ireland (Fig. 1), for further details see (Davis et al., 2010).

The site has been under cropland for over 50 years with sugar beet, spring barley, maize and oil seed rape planted in rotation until 2000. Since 2000 the site has been cropped continuously with spring barley. This study initially focuses on the years 2004-2006 due to the availability of suitable data. Full details of the site and soil characteristics are listed in Table 1. Land management details for the period are outlined in Table 2.

The site hosted an eddy covariance flux tower over the study period providing access to net ecosystem exchange measurements that were utilized in the study (Davis et al., 2010). Data available from the flux tower included meteorology, volumetric soil water content and NEE, from which $\mathrm{R}_{\text {eco }}$ was derived.

\subsubsection{Meteorological data}

Daily meteorological data were obtained from two sources: the Irish meteorological service, Met Éireann, who provided data from the nearby weather station located on the grounds of the Teagasc Oak Park Research Centre and the nearest synoptic station located in Kilkenny approximately $30 \mathrm{~km}$ away (1), and the flux tower stationed in the experimental field, covering the period from 2004 to 2006 (2). As 7\% of the data from 2004 to 2006 were missing from the Oak Park meteorological station, gaps were subsequently infilled using either the flux tower or Kilkenny synoptic station data, in that order. As long-term data were not available

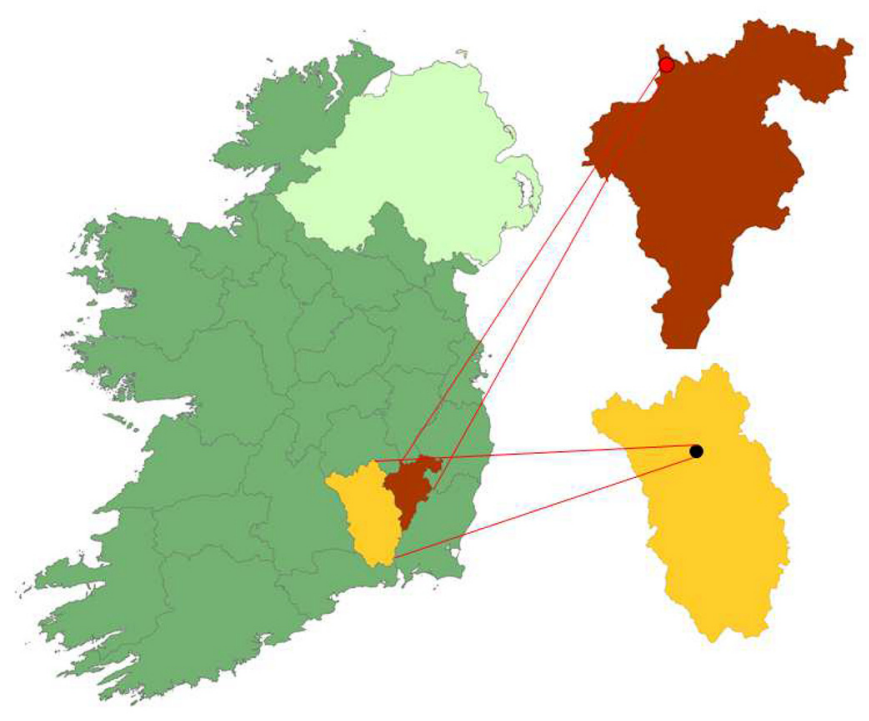

Fig. 1. Republic of Ireland showing Kilkenny (yellow) and Carlow (brown) with Kilkenny synoptic station (black point) and case study location Oak Park (red point). from Oak Park, data from the nearby Kilkenny synoptic station were obtained to derive the 30-year averages used for model spin-up (in which soil C is brought to equilibrium). Meteorological and climatological information utilized for the study is shown in Fig. 2.

Potential evapotranspiration (PE) values were unavailable for the Oak Park site for the years 2004-2006. Consequently, daily values for PE for the period of interest were initially estimated using the Hargreaves method (Hargreaves and Samani, 1985). Since 2008 when the weather station was upgraded, Met Éireann have derived estimates of PE using the FAO-56 Penman-Monteith method, facilitating an evaluation of the Hargreaves method over the period 2008 to 2016. This evaluation indicated a significant overestimation of PE values derived using the Hargreaves approach when compared to the Met Éireann calculated values. A linear calibration was derived from the 2008 to 2016 period and subsequently applied to the Hargreaves estimated values for the 2004 to 2006 period, resulting in modified PE values which were used as input to the model. Fig. 3 illustrates the cumulative sums for the years 2008 to 2010 based on the original Hargreaves method, the modified Hargreaves estimates and the Met Éireann derived PE values. A difference in annual accumulations of $\sim 100 \mathrm{~mm}$ is evident between the pre- and post- modified Hargreaves values.

\subsubsection{Soil respiration}

As $R_{\text {eco }}$ represents the combined soil auto- and hetero- trophic respiration, the daily $R_{\text {eco }}$ values was subsequently partitioned between the gross autotrophic and heterotrophic components. This was achieved by running DNDC (DeNitrification-DeComposition; (Giltrap et al., 2010)), using the same inputs and weather data outlined previously, to derive

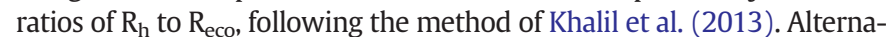
tively, Hardie et al. (2009) propose that $R_{h}$ is between 46 and $59 \%$ of $R_{\text {eco }}$; Abdalla et al. (2014) split this seasonally so that $R_{h}$ is assumed to be at its lowest at $46 \%$ during summer (JJA), 59\% during winter (DJF) with a mean value (52.5\%) for the rest of the year. Both these methods produced a similar temporal signal but the cumulative fluxes were found to be higher for the seasonal method (Fig. 4).

Dondini et al. (2017) suggest that since ECOSSE simulates GHG fluxes from the soil layers defined by the user, whereas the flux data represents fluxes from the entire soil profile, model output will fall below the estimated $R_{h}$. Due to these complexities in partitioning flux tower data into autotrophic and heterotrophic components, soil respiration measurements using chamber data was ultimately prioritized as more useful for model evaluation. However, soil respiration from the chamber data was only available for 2004, a limiting factor on the present study. Soil chamber measurements of $\mathrm{CO}_{2}$ fluxes, obtained from Jones et al (2010), were measured using a CIRAS 2 infra-red gas analyzer coupled to static chambers (SRC-1 soil respiration chamber, PP Systems, Hitchin, Herts, UK). The system allowed automated in-field soil $\mathrm{CO}_{2}$ flux measurements every 20-90 min. Twelve collars were inserted to a depth of $5 \mathrm{~cm}$ into the soil 12 days before measurements began to alleviate the effect of soil disturbance on the fluxes. While it is likely that the measurements from the soil chambers include both components of heterotrophic $\left(R_{h}\right)$ and autotrophic $\left(R_{a}\right)$ respiration, the soil chamber data does provides an upper limit to Rs in which to assess the model.

\subsubsection{Soil moisture}

Volumetric soil water content (SWC) (\%) measurements at the flux tower were also available for the period 2004-2006. The SWC data, obtained from a previous study (Davis et al., 2010), was measured using a CS616 Water Content Reflectometer (Campbell Scientific) to a depth of $20 \mathrm{~cm}$. The measured Soil Water Content (SWC) in the field ranged from $3.92 \%$ to $27.14 \%$ with a mean of $16.95 \%$, over the period of measurement. As the SWC was measured at a $20 \mathrm{~cm}$ depth, for comparison with the ECOSSE model which requires water content to be specified to $25 \mathrm{~cm}$, the SWC volume percentage was estimated to a depth of $25 \mathrm{~cm}$ and converted to $\mathrm{mm}$. Field experiments indicate that volumetric water content at relatively shallow depths does not vary greatly, indicating that this 
Table 1

Oak Park Site Characteristics (adapted from observed data, (Khalil et al., 2013) and (Abdalla et al., 2009a)).

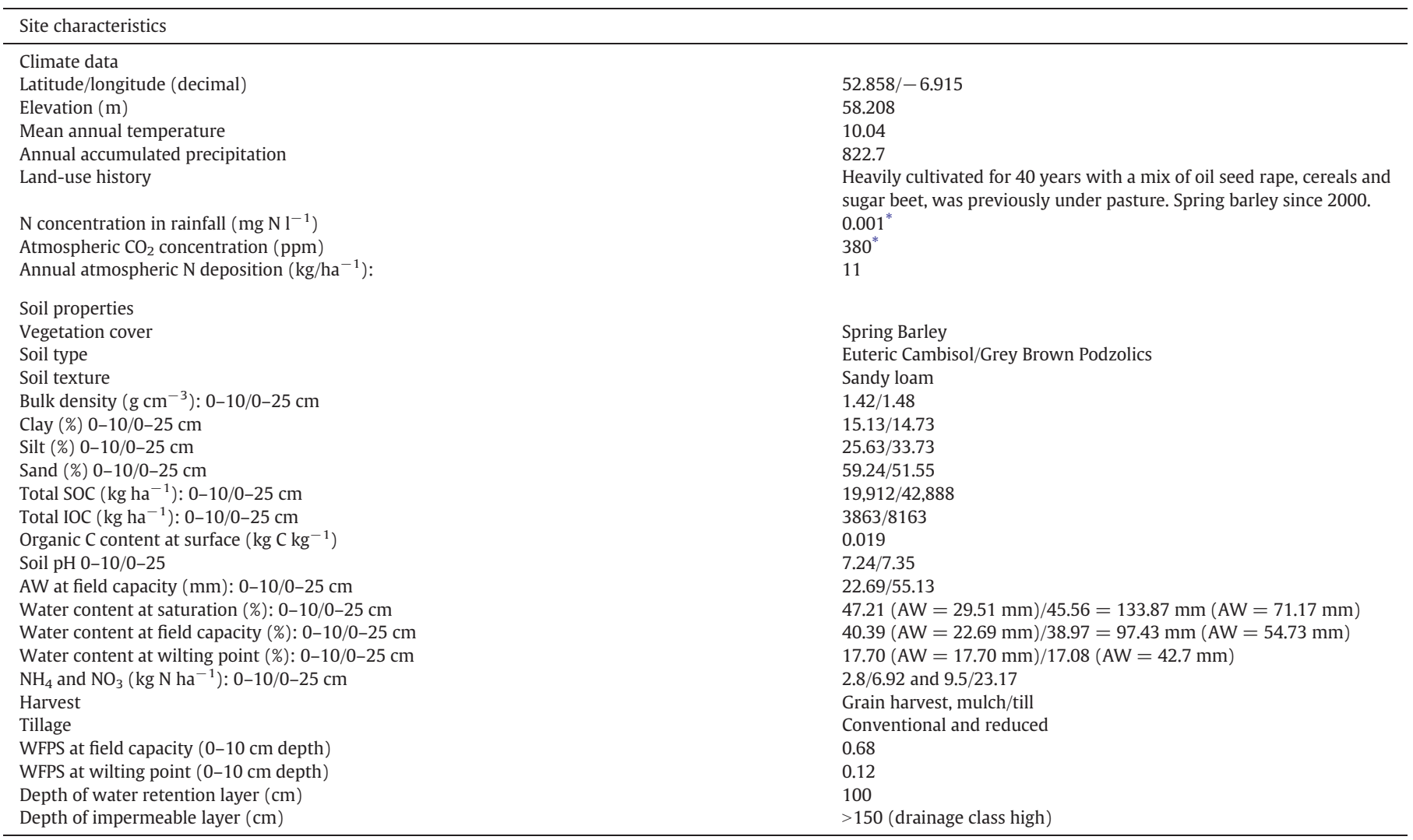

* Default Values.

method is appropriate (Qiu et al., 2001; Quesada et al., 2004; Tromp-van Meerveld and McDonnell, 2006; Martin et al., 2012). The derived SWC ranged in values from 9.8 to $67.85 \mathrm{~mm}$, with an average of 42.25 and median of $45.2 \mathrm{~mm}$ over the period.

\section{Results \& discussion}

Fig. 4 illustrates the estimated $\mathrm{R}_{\mathrm{eco}}$, derived from measurements taken at the flux tower, $\mathrm{R}_{\mathrm{h}}$ partitioned from $\mathrm{R}_{\mathrm{eco}}$ using the two previously described methods and ECOSSE simulated $\mathrm{R}_{\mathrm{h}}$ using the model parameters outlined in Tables 1 and 2. A marked difference is evident between the ECOSSE simulated soil heterotrophic respiration $\left(R_{h}\right)$ values and $R_{h}$ values derived using the methods outlined above. While not unexpected, largely due to the uncertainties associated with partitioning the net flux $R_{\text {eco }}$ between its two gross components $\left(R_{a}\right.$ and $\left.R_{h}\right)$, the results are in marked contrast to previous studies from the site which employed a similar approach (Khalil et al., 2013; Khalil, 2015).

Liu et al. (2006) previously found a strong correlation between soil $\mathrm{CO}_{2}$ efflux and the daily variation of photosynthetically active radiation

Table 2

Management timeline of spring barley fertilized with CAN NitroSulphur.

\begin{tabular}{lllll}
\hline & 2003 & 2004 & 2005 & 2006 \\
\hline Crop 1 sow & $20 / 03 / 2003$ & $26 / 03 / 2004$ & $14 / 03 / 2005$ & $20 / 03 / 2006$ \\
Crop 1 harvest & $23 / 08 / 2003$ & $26 / 08 / 2004$ & $08 / 08 / 2005$ & $01 / 08 / 2006$ \\
Fert 1 Date & $15 / 04 / 2003$ & $27 / 04 / 2004$ & $16 / 04 / 2005$ & $12 / 04 / 2006$ \\
Fert 1 (kg N/ha) & 137 & 140 & 109 & 89.91 \\
Fert 2 Date & - & - & $10 / 05 / 2005$ & $11 / 05 / 2006$ \\
Fert 2 (kg N/ha) & - & - & 55 & 50 \\
Crop 2 type & - & - & Mustard Cover & - \\
Crop 2 sow & - & - & $12 / 09 / 2005$ & - \\
Crop 2 harvest & - & - & $21 / 02 / 2006$ & - \\
\hline
\end{tabular}

(PAR). On investigation, a temporal offset is evident between the timing of peak radiation and temperature at Oak Park, with leaf area index, here used as a proxy for plant growth, more closely corresponding with radiation (Fig. 5). The seasonality of $\mathrm{R}_{\text {eco }}$ is dominated by above ground plant respiration (Barr et al., 2004; Matteucci et al., 2015), in turn reflecting the seasonal growth of plants. Hence, any partitioning of $R_{\text {eco }}$ to derive $R_{h}$ will ultimately reflect this seasonality. As $R_{h}$ variability in ECOSSE is primarily influenced/modified by temperature, an offset in model simulated $R_{h}$ will result. However, the offset in timing between radiation and temperature at the site is not sufficient to account for the difference between the model simulated and estimated values of $\mathrm{R}_{\mathrm{h}}$.

Subsequently, soil chamber measurements for 2004 were used to compare to the model simulated $R_{h}$, as chamber measurements are

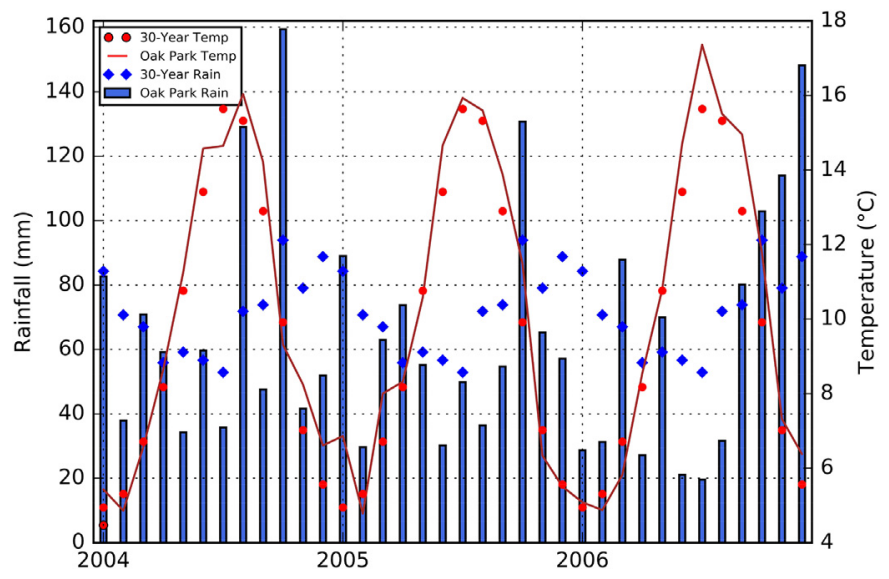

Fig. 2. Meteorology for 2004-2006 for Oak Park and 30 year climatology from 1974 to 2003 from Kilkenny synoptic station ( $30 \mathrm{~km}$ from Oak Park). 


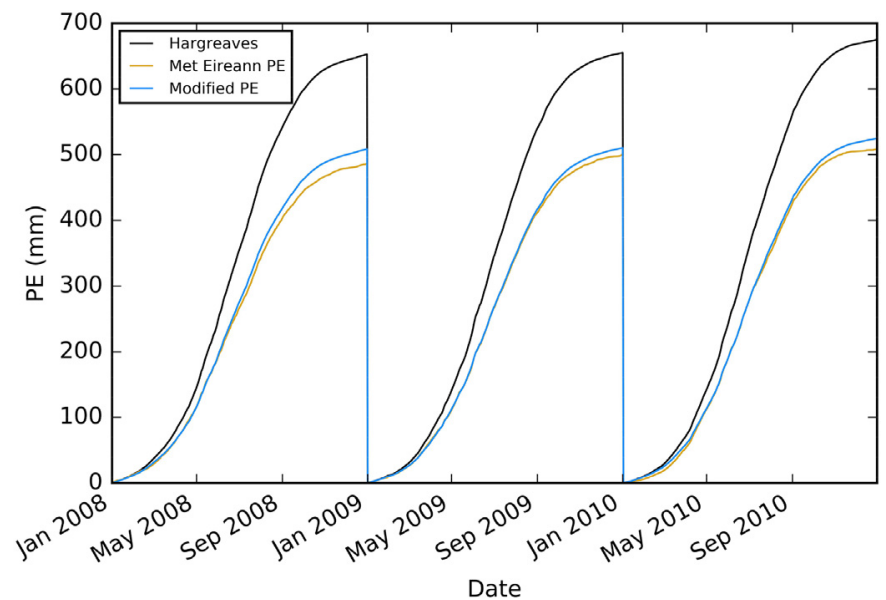

Fig. 3. Cumulative PE illustrating the overestimation derived using the Hargreaves calculation, compared to Met Éireann PE and PE modified, using calibration equation.

considered more reliable than flux partitioned ecosystem respiration (Dondini et al., 2017) (Fig. 6). The simulated $\mathrm{R}_{\mathrm{h}}$ values appear much closer to the $\mathrm{CO}_{2}$ soil chamber measurements after August, indicating that the model is capturing a component of the measured soil respiration. However, the model simulation does not replicate the measured soil chamber values during the plant growing season, from April to August (crop sowing date: 25 March; crop harvest date: 25 August).

To investigate this, the modifier equations outlined in Section 2.1.1 were applied to the meteorological data at the site to investigate potential sources of error in the timing and magnitude of the ECOSSE simulated values.

\subsection{Temperature modifier}

For comparison, the comparable component expressions from Eq. (1) (Lloyd and Taylor, 1994) and 2 (Jacobs et al., 2007) were employed along with the ECOSSE temperature modifier (Eq. (3)) (Smith et al., 2010a) to simulate soil respiration at the site. Fig. 7 shows the simulated soil respiration response to temperature based on each of these methods, which all produce results positively correlated with the measured soil chamber data (Spearman's Rho of 0.848 for each, significant at the 0.01 level). Despite the Jacobs et al. (2007) equation being derived for grasslands, the outcome is consistent with both the ECOSSE and Lloyd and Taylor expressions.

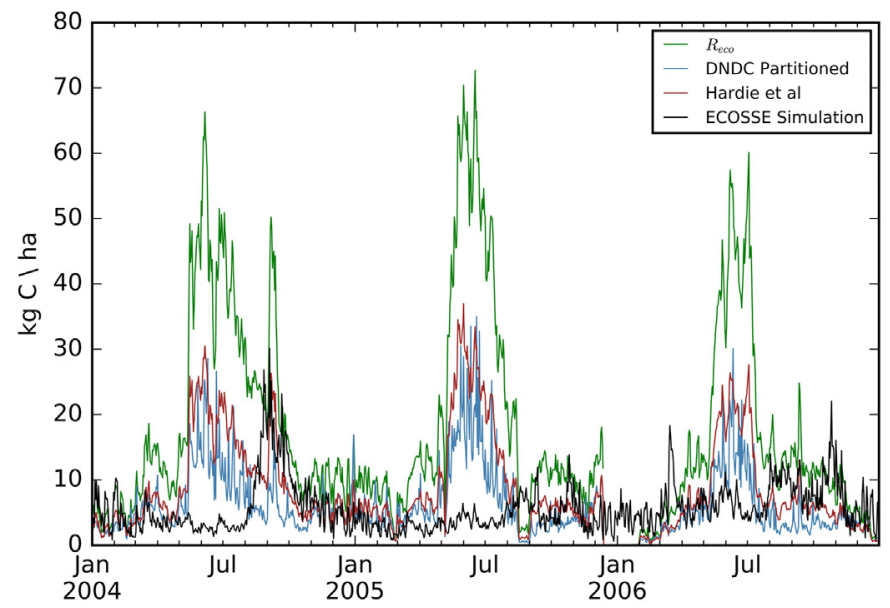

Fig. 4. Comparison between $R_{\text {eco }}$, estimated from measurements at the flux tower, $R_{h}$ partitioned using relative proportions $\left(\mathrm{R}_{h} / \mathrm{R}_{\text {eco }}\right)$ from DNDC (following Khalil et al., 2013), $R_{h}$ partitioned using the method of Hardie et al. (2009) and ECOSSE model simulated $R_{h}$, over the period 2004-2006.

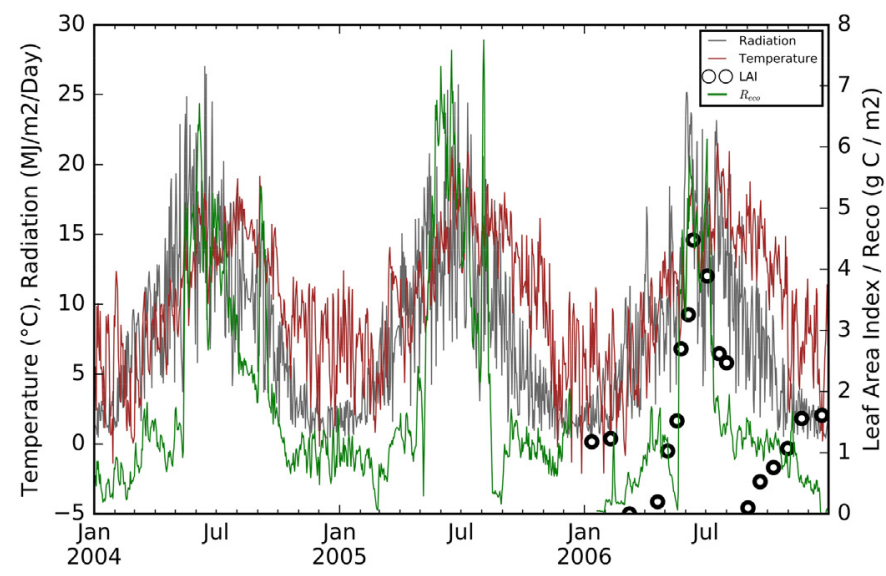

Fig. 5. Radiation, $\mathrm{R}_{\text {eco, }}$ temperature (2004-2006) and leaf area index (LAI) (2006) measured at the site.

\subsection{Water modifier}

The ECOSSE water modifier was then applied (Eq. (5)) to the model simulated available water (AW); available as an output from the model for each $5 \mathrm{~cm}$ soil layer. For the purposes of this evaluation, the water modifier was applied to the simulated available water, accumulated over each $5 \mathrm{~cm}$ layer to a depth of $25 \mathrm{~cm}$. While the soil depth in the ECOSSE model simulation was set to a depth of $45 \mathrm{~cm}$, the dominant soil efflux typically arises from the upper most layers - SUNDIAL allocates $80 \%$ of SOM to the $0-25 \mathrm{~cm}$ layers - (Bradbury et al., 1993), and for simplification, only the AW accumulation to $25 \mathrm{~cm}$ was used. Also, the selection of this depth allowed for a direct comparison with soil water content derived from measurements. Evident from Fig. 8, the model simulated AW and consequently, the water modifier $\left(\mathrm{m}_{\mathrm{w}}\right)$ has a significant impact on the simulated $\mathrm{CO}_{2}$ fluxes; results from applying both the temperature and water modifier closely replicate the ECOSSE model simulated values, indicating the importance of model simulated soil water content.

\subsection{Crop and $\mathrm{pH}$ modifiers}

Finally, the crop $\left(\mathrm{m}_{\mathrm{crop}}\right)$ and $\mathrm{pH}\left(\mathrm{m}_{\mathrm{pH}}\right)$ modifiers were applied. The crop modifier follows Jenkinson (1977) and applies a rate of 0.6 when the crop is growing, and 1 when the crop is absent. This acts to further reduce the $\mathrm{CO}_{2}$ efflux during the growing season; but, in spite of the threshold value applied (i.e. 0.6) its effect is proportionately small due to the previous effect of the water modifier. The modifier of 0.6 is

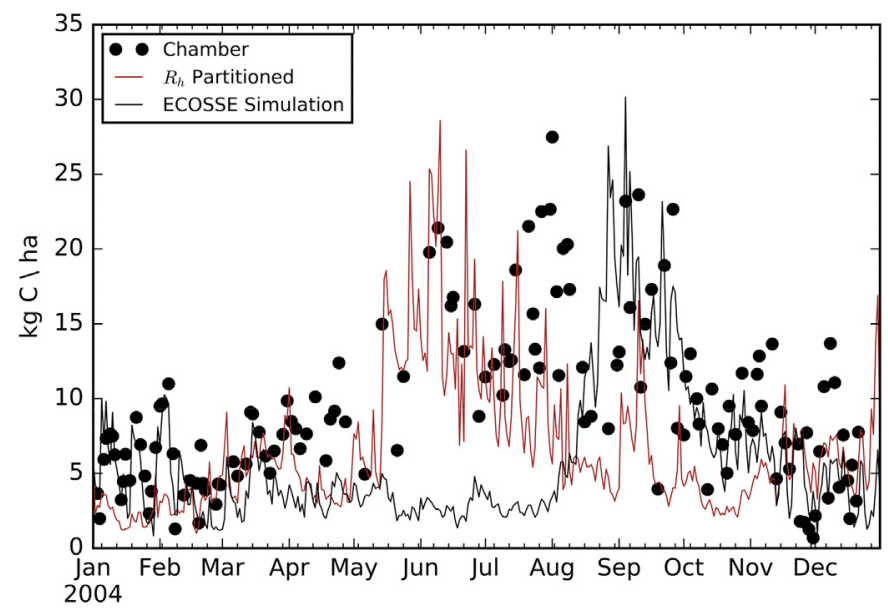

Fig. 6. Comparison between model simulated $R_{h}, R_{h}$ partitioned using DNDC and measured soil respiration from the soil chamber experiment for 2004. 


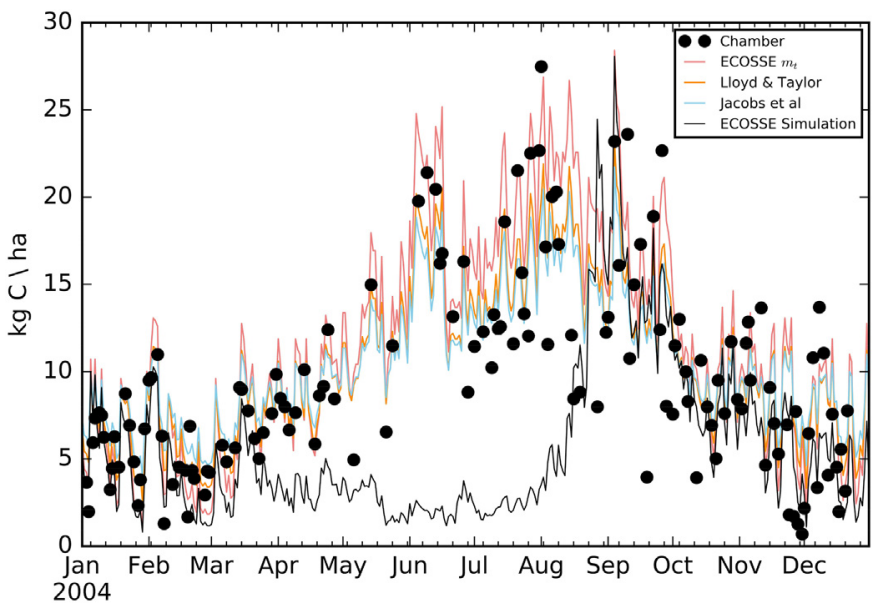

Fig. 7. Temperature modifiers (coloured lines), chamber data (dots) and model output (solid black line) for 2004.

arguably an arbitrary one, future work could examine the potential for amplified respiration resulting from increased root growth and microbial activity as plants grow.

As soil $\mathrm{pH}$ is near neutral $(\mathrm{pH} \sim 7.3)$ at the site, the modifier is assumed to be 1, similar to RothC and SUNDIAL (Coleman and Jenkinson, 1996; Bradbury et al., 1993) for well managed arable soils and thus had no impact on the calculated soil efflux.

\subsection{Comparison with measured SWC}

As a combination of the ECOSSE simulated AW and water modifier were found to have the largest impact on the simulated soil efflux, the model simulated AW was initially compared to the measured soil water content (volumetric \% converted to $\mathrm{mm}$ over $25 \mathrm{~cm}$ depth) (Fig. 9). While the ECOSSE model appears to capture the timing and duration of soil drying, the model overestimates the magnitude. This is particularly evident in 2004, where the measured SWCs remain high (no water stress), but the model simulated AW indicates complete drying of the soil layers to $25 \mathrm{~cm}$ (water stress). During 2005 and 2006, the measured SWCs indicate drying of the soil layers, but the model simulated AW again overestimates the magnitude, with complete drying of the model soil layers for $\sim 10$ weeks in 2005 and $\sim 3$ weeks in 2006.

As measured SWC values were available, the ECOSSE water modifier was applied to the SWC estimated to $25 \mathrm{~cm}\left(m_{w}(S W C)\right)$, based on the volumetric SWC measurements, rather than the model simulated AW.

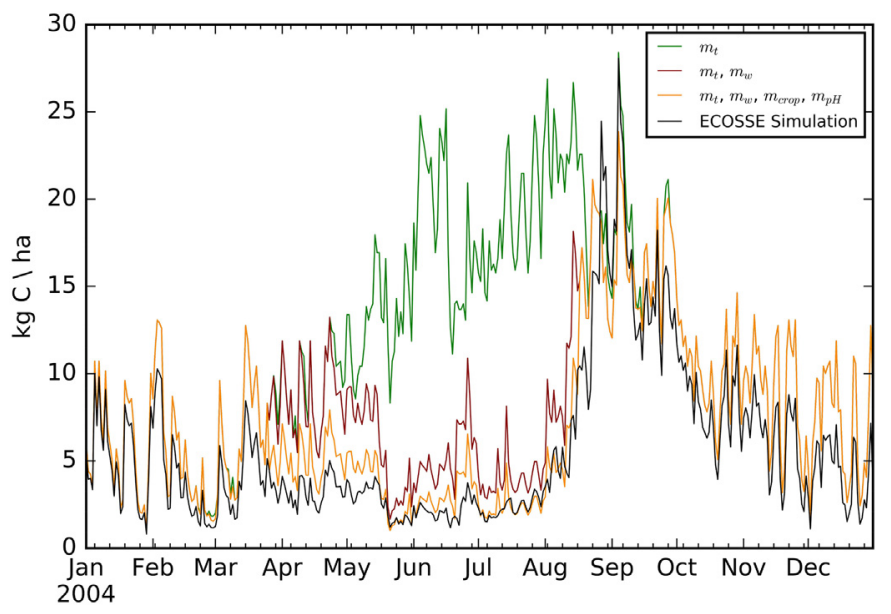

Fig. 8. ECOSSE modifiers applied as follows, temperature $\left(\mathrm{m}_{\mathrm{t}}\right)$, temperature \& water $\left(\mathrm{m}_{\mathrm{t}}\right.$, $\left.\mathrm{m}_{\mathrm{w}}\right)$, temperature, water, crop and $\mathrm{pH}\left(\mathrm{m}_{\mathrm{t}}, \mathrm{m}_{\mathrm{w}}, \mathrm{m}_{\mathrm{crop}}, \mathrm{m}_{\mathrm{pH}}\right)$, and ECOSSE model simulated soil respiration.

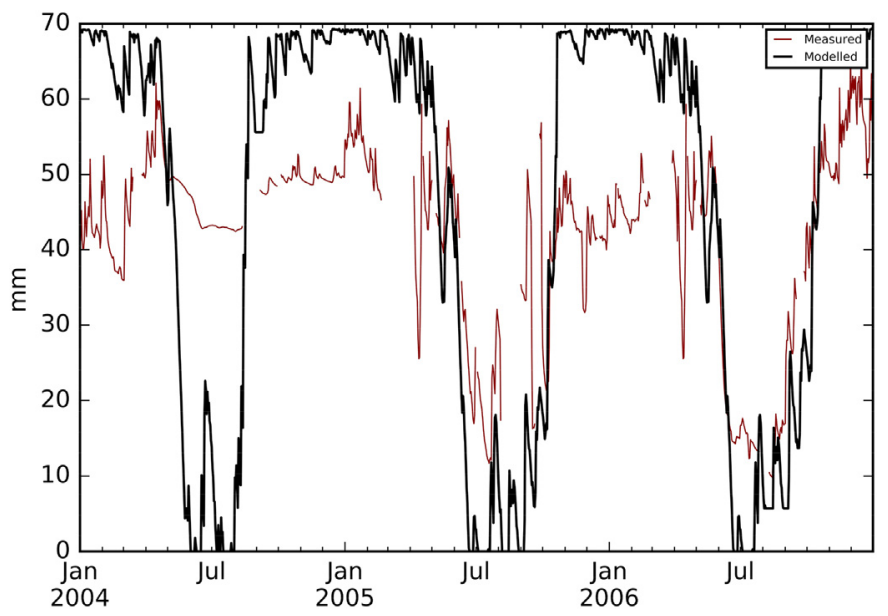

Fig. 9. Soil Water Content derived for a depth to $25 \mathrm{~cm}$, based on measured volumetric soil water content and ECOSSE modelled available water based on an accumulation of each $5 \mathrm{~cm}$ layer to a depth of $25 \mathrm{~cm}$.

The results from this indicate a much lower suppression of soil respiration, relative to the ECOSSE model simulated values (Fig. 10), particularly during the plant growing season. This is evidenced by lower RMSE and MAE values for the empirical model using $m_{w}(S W C)$ compared to the actual ECOSSE model output; similarly, higher correlations are evident between the empirical model using $m_{w}(S W C)$ and the chamber measurements (Table 3).

\subsection{Model sensitivity to available water model parameter}

Inconsistent reporting of available water content and differences in the pattern of soil $\mathrm{CO}_{2}$ emissions resulting from different available water inputs motivated further research into the impact of different AW model parameter values. In the absence of direct field measurements of soil water tension, field capacity, water content at wilting point and water available at saturation are typically estimated using pedotransfer functions (after Saxton and Rawls, 2006); in order to determine soil water characteristics based on soil parameters at varying tensions. US based literature widely denotes $-33 \mathrm{kPa}$ as the tension at field capacity and $-1500 \mathrm{kPa}$ the tension at wilting point; AW is then the difference between the two. However, soil tension at field capacity estimates can range from $\sim-10 \mathrm{kPa}$ for sandy soils to $-33 \mathrm{kPa}$ for

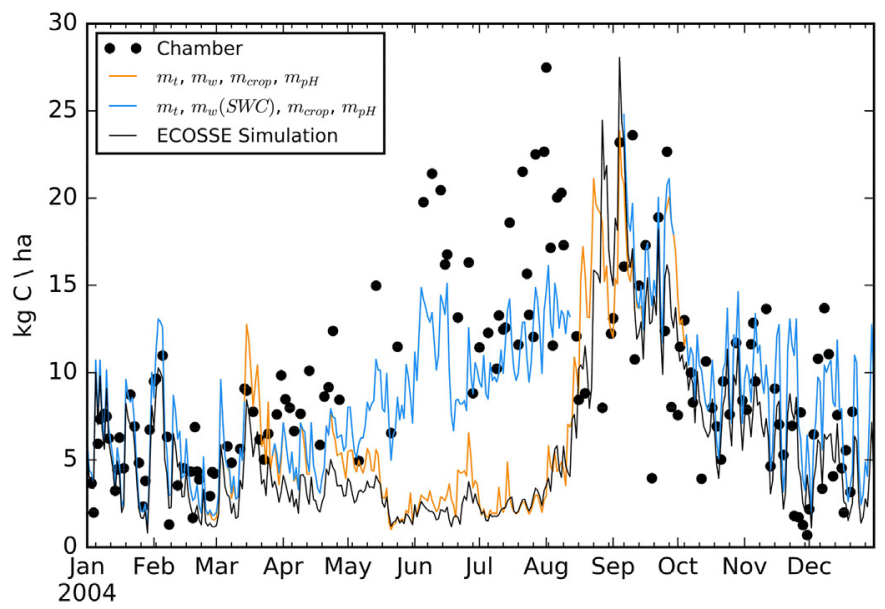

Fig. 10. ECOSSE modifiers $\left(\mathrm{m}_{\mathrm{t}}, \mathrm{m}_{\mathrm{w}}, \mathrm{m}_{\mathrm{crop}}, \mathrm{m}_{\mathrm{pH}}\right)$ applied to both model simulated available water (yellow line) and using measured SWC (blue line). Soil chamber measurements are also plotted, along with the ECOSSE model simulated values. 
Table 3

Correlation (grey) MAE and RMSE (white) for modelled SWC, observed SWC and model simulated $\mathrm{R}_{\mathrm{h}}$.

\begin{tabular}{llll}
\hline & $\mathrm{m}_{\mathrm{t}}, \mathrm{m}_{\mathrm{w}}, \mathrm{m}_{\text {crop }}, \mathrm{m}_{\mathrm{pH}}$ & $\mathrm{m}_{\mathrm{t}}, \mathrm{m}_{\mathrm{w}}(S W C), \mathrm{m}_{\mathrm{crop}}, \mathrm{m}_{\mathrm{pH}}$ & Model \\
\hline Chamber & 0.154 & $0.775^{*}$ & $0.238^{*}$ \\
Model & $0.961^{*}$ & $0.515^{*}$ & 1 \\
MAE $^{\mathrm{a}}$ & 4.97 & 2.81 & 5.25 \\
RMSE $^{\mathrm{a}}$ & 7.21 & 3.78 & 7.38 \\
\hline
\end{tabular}

* Correlation is significant at the 0.01 level.

a MAE and RMSE compare the chamber data to $\mathrm{R}_{\mathrm{h}}$ derived from the ECOSSE modifiers, modifiers using SWC, and model simulated $R_{h}$.

loam and clay loam soils (Paul, 2006) with Irish soils being 'commonly near $-5 \mathrm{kPa}$ ' (Keane, 2004, pg. 85), further increasing the upper range of available water estimates. Using pedotransfer functions at $33 \mathrm{kPa}$ a sandy loam soil has $\sim 12 \%$ available water, at $-10 \mathrm{kPa}$ the same soil has $29 \%$ available water. This gives a potential range of available water from 30 to $72.5 \mathrm{~mm} / 25 \mathrm{~cm}$ depending on $\mathrm{kPa}$ chosen for field capacity; available water to $25 \mathrm{~cm}$ is required as an input parameter to the model.

Table 3 shows the results of pedotransfer equations for the sandy loam soil at Oak Park based on Saxton and Rawls (2006). These values differ from those reported by Abdalla et al. (2009b) who report water filled pore space (WFPS) at field capacity and wilting point, and from Khalil et al. (2013) who report AW at field capacity as $55.13 \mathrm{~mm}$ for $0-25 \mathrm{~cm}$.

Changes to the AW input parameter of the model were found to impact the timing, but not the magnitude of $\mathrm{CO}_{2}$ fluxes, while changes to water available at saturation and water content at wilting point have no apparent impact on simulated $\mathrm{CO}_{2}$. Fig. 11 illustrates the ECOSSE model output with the range of ten experimental runs using AW values from 20 to $110 \mathrm{~mm}$ (wilting point to saturation for this soil - Table 4), and the 5 and $95 \%$ confidence intervals around these experiments.

As modifying the available water parameter in the model was found not to influence the resultant $\mathrm{CO}_{2}$ fluxes, adjustments to clay content were performed to investigate the effects of soil structure on drainage. Sensitivity testing of both clay and sand content in the soil yielded no change in the excessive drainage or $\mathrm{CO}_{2}$ output of the model, changes to the 'drainage class' of the soil also showed no change. Reducing PE or increasing precipitation did affect soil moisture and $\mathrm{CO}_{2}$ outputs, but it is difficult to justify artificial irrigation when not based in reality.

\section{Conclusion}

The development and application of models has a key role to play in improving our understanding of soil carbon science but also in informing and supporting future decisions on appropriate LULUCF management

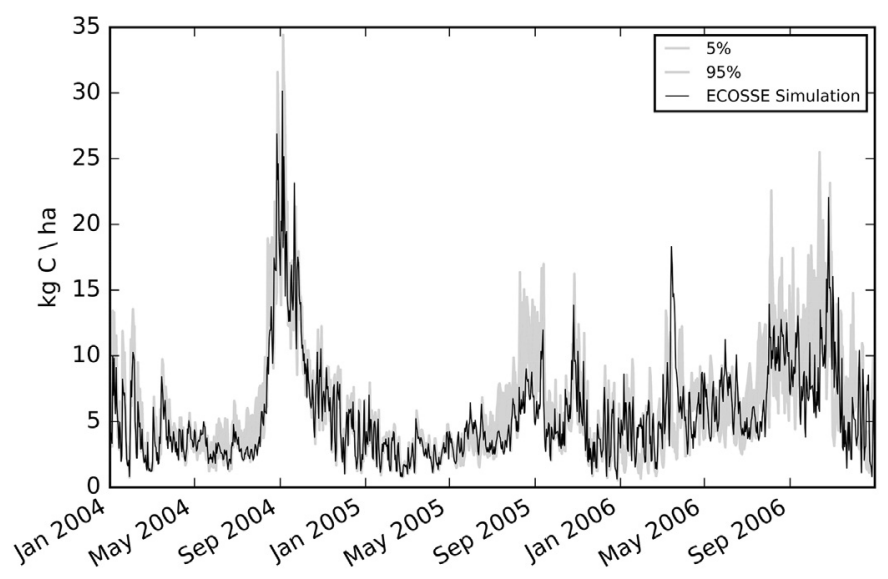

Fig. 11. ECOSSE model sensitivity to available water (AW) with mean values displayed as a solid black line and grey shading indicating the 5 and $95 \%$ confidence intervals.
Table 4

Moisture characteristics from pedotransfer functions.

\begin{tabular}{lll}
\hline Sandy loam & \% Moisture & $250 \mathrm{~mm}$ \\
\hline Saturation $(0 \mathrm{kPa})$ & 44.6 & 111.5 \\
Field capacity $(10 \mathrm{kPa})$ & 38.2 & 95.5 \\
Wilting point $(1500 \mathrm{kPa})$ & 10.4 & 26 \\
Available water $(\mathrm{FC}-\mathrm{WP})$ & 27.8 & 69.5 \\
\hline
\end{tabular}

options. However, prior to their use in decision making, such model needs to be widely evaluated.

The ECOSSE model has been widely applied on mineral soils previously, principally for grassland systems. The current study evaluated the model under an arable system on a free draining soil and was found it was deficient in simulating available water. Investigating the modifiers applied by the model to input data indicates that the simulation of soil water in site-specific mode provides an inaccurate representation compared to estimates of SWC derived from measurements, and in turn significantly impacts the simulation of soil respiration relative to soil chamber measurements. This may be due to the fact that tillage systems (particularly on free-drained sandy soils) are highly dynamic. The use of observed SWC data as input to the water modifier equation clearly illustrates that excessive drainage of water in the model is suppressing $\mathrm{CO}_{2}$ fluxes from the soil, a trend not replicated in the observations. Model performance is significantly improved using observed SWC data, which show a much higher correlation with chamber measurements than the ECOSSE modelled respiration ( $r^{2}$ of 0.775 vs 0.154 ). This excessive drainage cannot be counteracted by adjusting relevant model parameters indicating a revision of the ECOSSE water component is needed for this model to perform optimally for arable systems on mineral soils. While using ECOSSE for the estimation of soil organic carbon sequestration from cropping systems may prove to be robust as this is often observed on a decadal scale based on cumulative annual fluxes, these findings have implications for the simulation of greenhouse gas emissions (particularly $\mathrm{CO}_{2}$ respiration and $\mathrm{N}_{2} \mathrm{O}$ emissions) for mineral soil-based crop systems.

To generalize the results; 2004 represented a year in which the observed and model soil water displayed the greatest divergence, hence the effects on soil respiration are also likely to be greatest as a consequence. While 2004 may represent an 'anomalous' model year in terms of simulated water, such events provide an opportunity to investigate model response more fully. To what degree are the findings specific to the year and the case study location? At least one other study has highlighted a similar model deficiency in soil water content (Bell et al., 2011). If these models are to provide useful guidance to inform mitigation strategies of future soil emissions, then they need to demonstrate a robust response to a broad range of meteorological conditions that could arise as a consequence of changes in the climate system.

A comprehensive framework for model evaluations is ultimately required; identifying a global network of sites with the requisite model input and evaluation data facilitating a more comprehensive intercomparison of models. The identification of outlier events, such as 2004, for use in evaluations would also provide a focus to where greater research effort could be directed. The ultimate aim of which is to demonstrate the utility of these models and provide confidence in their use for informing policy.

\section{Acknowledgements}

The authors would like to express gratitude to Teagasc for funding this research under the Teagasc Walsh Fellowship progamme, to the Environmental Modelling group at Aberdeen University (particularly Mike Williams, Marta Dondini and Jo Smith) for providing their invaluable help and expertise with running the model. Thanks also to the two anonymous reviewers for their helpful and insightful comments. The authors are also grateful to the many people who undertook monitoring and 
measurements of the relevant observations at the site over the many years which made aspects of this research feasible.

\section{References}

Abdalla, M., Jones, M., Ambus, P., Williams, M.,2009a. Emissions of nitrous oxide from Irish arable soils: effects of tillage and reduced $\mathrm{N}$ input. Nutr. Cycl. Agroecosyst. 86: 53-65. https://doi.org/10.1007/s10705-009-9273-8.

Abdalla, M., Wattenbach, M., Smith, P., Ambus, P., Jones, M., Williams, M., 2009b. Application of the DNDC model to predict emissions of N2O from Irish agriculture. Geoderma 151:327-337. https://doi.org/10.1016/j.geoderma.2009.04.021.

Abdalla, M., Hastings, A., Bell, M.J., Smith, J.U., Richards, M., Nilsson, M.B., Peichl, M. Löfvenius, M.O., Lund, M., Helfter, C., Nemitz, E., Sutton, M.A., Aurela, M., Lohila, A Laurila, T., Dolman, A.J., Belelli-Marchesini, L., Pogson, M., Jones, E., Drewer, J. Drosler, M., Smith, P., 2014. Simulation of CO2 and attribution analysis at six European peatland sites using the ECOSSE model. Water Air Soil Pollut. 225, 2182 https://doi.org/10.1007/s11270-014-2182-8.

Barr, A.G., Black, T.A., Hogg, E.H., Kljun, N., Morgenstern, K., Nesic, Z., 2004. Inter-annual variability in the leaf area index of a boreal aspen-hazelnut forest in relation to net ecosystem production. Agric. For. Meteorol. 126:237-255. https://doi.org/10.1016/ j.agrformet.2004.06.011.

Bell, M.J., Jones, E., Smith, J., Smith, P., Yeluripati, J., Augustin, J., Juszczak, R., Olejnik, J., Sommer, M., 2011. Simulation of soil nitrogen, nitrous oxide emissions and mitigation scenarios at 3 European cropland sites using the ECOSSE model. Nutr. Cycl. Agroecosyst. 92:161-181. https://doi.org/10.1007/s10705-011-9479-4.

Bond-Lamberty, B., Thomson, A., 2010. Temperature-associated increases in the globa soil respiration record. Nature 464, 579-584

Bradbury, N.J., Whitmore, A.P., Hart, P.B.S., Jenkinson, D.S., 1993. Modelling the fate of nitrogen in crop and soil in the years following application of $15 \mathrm{~N}$-labelled fertilizer to winter wheat. J. Agric. Sci. 121:363-379. https://doi.org/10.1017/S0021859600085567.

Carlyle, J.C., Than, U.B., 1988. Abiotic controls of soil respiration beneath an eighteen-yearold Pinus radiata stand in South-Eastern Australia. J. Ecol. UK 76 (3), 654-662 (Forestry S.).

Coleman, K., Jenkinson, D.S., 1996. RothC-26.3 - a Model for the Turnover of Carbon in Soil. Evaluation of Soil Organic Matter Models, NATO ASI Series. Springer, Berlin, Heidelberg:pp. 237-246 https://doi.org/10.1007/978-3-642-61094-3_17.

Coleman, K., Jenkinson, D., 2014. RothC - a Model for the Turnover of Carbon in Soil.

Cook, F.J., Orchard, V.A., 2008. Relationships between soil respiration and soil moisture. Soil Biol. Biochem. 40:1013-1018. https://doi.org/10.1016/j.soilbio.2007.12.012.

Davis, P.A., Brown, J.C., Saunders, M., Lanigan, G., Wright, E., Fortune, T., Burke, J., Connolly, J., Jones, M.B., Osborne, B., 2010. Assessing the effects of agricultural management practices on carbon fluxes: spatial variation and the need for replicated estimates of net ecosystem exchange. Agric. For. Meteorol. 150:564-574. https://doi.org/10.1016/ j.agrformet.2010.01.021.

Dondini, M., Richards, M., Pogson, M., Jones, E.O., Rowe, R.L., Keith, A.M., McNamara, N.P. Smith, J.U., Smith, P., 2016a. Evaluation of the ECOSSE model for simulating soil organic carbon under Miscanthus and short rotation coppice-willow crops in Britain. GCB Bioenergy 8:790-804. https://doi.org/10.1111/gcbb.12286.

Dondini, M., Richards, M.I.A., Pogson, M., McCalmont, J., Drewer, J., Marshall, R., Morrison, R., Yamulki, S., Harris, Z.M., Alberti, G., Siebicke, L., Taylor, G., Perks, M., Finch, J. McNamara, N.P., Smith, J.U., Smith, P., 2016b. Simulation of greenhouse gases following land-use change to bioenergy crops using the ECOSSE model: a comparison between site measurements and model predictions. GCB Bioenergy 8:925-940. https:// doi.org/10.1111/gcbb.12298.

Dondini, M., Alberti, G., Delle Vedove, G., Ventura, M., Tonon, G., Viger, M., Harris, Z.M., enkins, JR Richards, M., Pogson, M. Taylor, G, Smith, J.U, Smith, P., 2017. Evaluation of the ECOSSE model to predict heterotrophic soil respiration by direct measurements. Eur. J. Soil Sci. 68:384-393. https://doi.org/10.1111/ejss.12416.

Giltrap, D.L., Li, C., Saggar, S., 2010. DNDC: a process-based model of greenhouse gas fluxes from agricultural soils. Agric. Ecosyst. Environ. 136:292-300 Estimation of nitrous oxide emission from ecosystems and its mitigation technologies. https://doi.org/ 10.1016/j.agee.2009.06.014.

Guntiñas, M.E., Gil-Sotres, F., Leirós, M.C., Trasar-Cepeda, C., 2013. Sensitivity of soil respiration to moisture and temperature. J. Soil Sci. Plant Nutr. 13, 445-461.

Hanson, PJ. Edwards, NT Garten, CT. Andrews, JA 2000. Separating root and soil microbial contributions to soil respiration: a review of methods and observations. Biogeochemistry 48:115-146. https://doi.org/10.1023/A:1006244819642.

Hardie, S.M.L., Garnett, M.H., Fallick, A.E., Ostle, N.J., Rowland, A.P., 2009. Bomb-14C analysis of ecosystem respiration reveals that peatland vegetation facilitates release of old carbon. Geoderma 153:393-401. https://doi.org/10.1016/j.geoderma.2009.09.002.

Hargreaves, Samani, 1985. Reference crop evapotranspiration from temperature. Appl. Eng. Agric. 1:96-99. https://doi.org/10.13031/2013.26773.

Högberg, P., Nordgren, A., Högberg, M.N., Ottosson-Löfvenius, M., Bhupinderpal-Singh, Olsson, P., Linder, S., 2005. Fractional contributions by autotrophic and heterotrophic respiration to soil-surface CO2 efflux in Boreal forests. SEB Exp. Biol. Ser. 251-267.

Houghton, R.A., 2003. Revised estimates of the annual net flux of carbon to the atmosphere from changes in land use and land management 1850-2000. Tellus Ser. B Chem. Phys. Meteorol. 55:378-390. https://doi.org/10.1034/j.1600-0889.2003.01450.x

Houghton, R.A., House, J.I., Pongratz, J., van der Werf, G.R., DeFries, R.S., Hansen, M.C., Le Quéré, C., Ramankutty, N., 2012. Carbon emissions from land use and land-cover change. Biogeosciences 9:5125-5142. https://doi.org/10.5194/bg-9-5125-2012.

Jacobs, A.F.G., Heusinkveld, B.G., Holtslag, A.A.M., 2007. Seasonal and interannual variability of carbon dioxide and water balances of a grassland. Clim. Chang. 82:163-177. https://doi.org/10.1007/s10584-006-9182-7.

Jenkinson, 1977. The turnover of soil organic matter in some of the Rothamsted classical experiments [Great Britain]. Soil Sci. 123, 298-305.
Jones, M., Osborne, B., Williams, M., Saunders, M., Lanigan, G., Burke, J., Davis, P., Abdalla, M., Clifton-Brown, J. Connolly, J., Kumar, S., Nagy, M., 2010. CLIMATE CHANGE - Accounting for Greenhouse Gas Sources and Sinks in Major Irish Land-Use Categories: Towards the Establishment of a co-Ordinating Centre for FLUX Measurements (CCFLUX) (No. 43), STRIVE. EPA, Dublin.

Keane Collins, 2004. Climate, Weather and Irish Agriculture. 2nd ed. AGMET.

Kessavalou, A., Mosier, A.R., Doran, J.W., Drijber, R.A., Lyon, D.J., Heinemeyer, O., 1998. Fluxes of carbon dioxide, nitrous oxide, and methane in grass sod and winter wheat-fallow tillage management. J. Environ. Qual. 27:1094-1104. https://doi.org/ 10.2134/jeq1998.00472425002700050015x

Khalil, M.I., 2015. Development of Methodologies and Modelling for Accounting Greenhouse Gases and Organic Carbon Stocks in Agricultural Soils (No. 136), STRIVE. EPA, Dublin.

Khalil, M.I., Richards, M., Osborne, B., Williams, M., Müller, C., 2013. Simulation and validation of greenhouse gas emissions and $\mathrm{SOC}$ stock changes in arable land using the ECOSSE model. Atmos. Environ. 81:616-624. https://doi.org/10.1016/ j.atmosenv.2013.09.038.

Khalil, M.I., Abdalla, M., Lanigan, G., Osborne, B., Müller, C., 2016. Evaluation of parametric limitations in simulating greenhouse gas fluxes from Irish arable soils using three process-based models. Agric. Sci. 07:503-520. https://doi.org/10.4236/as.2016.78051.

Liu, Q., Edwards, N.T., Post, W.M., Gu, L., Ledford, J., Lenhart, S., 2006. Temperatureindependent diel variation in soil respiration observed from a temperate deciduous forest. Glob. Chang. Biol. 12:2136-2145. https://doi.org/10.1111/j.13652486.2006.01245.x

Lloyd, J., Taylor, J.A., 1994. On the temperature dependence of soil respiration. Funct. Ecol. 8:315-323. https://doi.org/10.2307/2389824.

Martin, J.G., Phillips, C.L., Schmidt, A., Irvine, J., Law, B.E., 2012. High-frequency analysis of the complex linkage between soil $\mathrm{CO}(2)$ fluxes, photosynthesis and environmental variables. Tree Physiol. 32:49-64. https://doi.org/10.1093/treephys/tpr134.

Matteucci, M., Gruening, C., Goded Ballarin, I., Seufert, G., Cescatti, A., 2015. Components, drivers and temporal dynamics of ecosystem respiration in a Mediterranean pine forest. Soil Biol. Biochem. 88:224-235. https://doi.org/10.1016/j.soilbio.2015.05.017.

Oertel, C., Matschullat, J., Zurba, K., Zimmermann, F., Erasmi, S., 2016. Greenhouse gas emissions from soils-a review. Chem. Erde-Geochem. 76:327-352. https://doi.org/ 10.1016/j.chemer.2016.04.002.

Ostle, N.J., Smith, P., Fisher, R., Ian Woodward, F., Fisher, J.B., Smith, J.U., Galbraith, D., Levy, P., Meir, P., McNamara, N.P., Bardgett, R.D., 2009. Integrating plant-soil interactions into global carbon cycle models. J. Ecol. 97:851-863. https://doi.org/10.1111/j.13652745.2009.01547.x

Paul, E.A., 2006. Soil Microbiology, Ecology and Biochemistry. Academic Press.

Qiu, Y., Fu, B., Wang, J., Chen, L., 2001. Spatial variability of soil moisture content and its relation to environmental indices in a semi-arid gully catchment of the Loess Plateau, China. J. Arid Environ. 49:723-750. https://doi.org/10.1006/jare.2001.0828.

Quesada, C.A., Miranda, A.C., Hodnett, M.G., Santos, A.J.B., Miranda, H.S., Breyer, L.M., 2004. Seasonal and depth variation of soil moisture in a burned open savanna (campo Sujo) in Central Brazil. Ecol. Appl. 14:33-41. https://doi.org/10.1890/01-6017.

Raich, J.W., Schlesinger, W.H., 1992. The global carbon dioxide flux in soil respiration and its relationship to vegetation and climate. Tellus Ser. B Chem. Phys. Meteorol. 44: 81-99. https://doi.org/10.1034/j.1600-0889.1992.t01-1-00001.x.

Raich, J.W., Tufekciogul, A., 2000. Vegetation and soil respiration: correlations and controls. Biogeochemistry 48:71-90. https://doi.org/10.1023/A:1006112000616.

Reichstein, M., Beer, C., 2008. Soil respiration across scales: the importance of a modeldata integration framework for data interpretation. J. Plant Nutr. Soil Sci. 171: 344-354. https://doi.org/10.1002/jpln.200700075.

Saxton, K.E., Rawls, W.J., 2006. Soil water characteristic estimates by texture and organic matter for hydrologic solutions. Soil Sci. Soc. Am. J. 70 (5), 1569-1578.

Scharlemann, J.P., Tanner, E.V., Hiederer, R., Kapos, V., 2014. Global soil carbon: understanding and managing the largest terrestrial carbon pool. Cardiol. Manag. 5:81-91. https://doi.org/10.4155/cmt.13.77.

Singh, J.S., Gupta, S.R., 1977. Plant decomposition and soil respiration in terrestrial ecosystems. Bot. Rev. 43:449-528. https://doi.org/10.2307/4353928.

Smith, J.U., Bradbury, N.J., Addiscott, T.M., 1996. SUNDIAL: a PC-based system for simulating nitrogen dynamics in arable land. Agron. J. 88:38. https://doi.org/10.2134/ agronj1996.00021962008800010008x.

Smith, J., Gottschalk, P., Bellarby, J., Chapman, S., Lilly, A., Towers, W., Bell, J., Coleman, K. Nayak, D., Richards, M., Hillier, J., Flynn, H., Wattenbach, M., Aitkenhead, M., Yeluripati, J., Farmer, J., Milne, R., Thomson, A., Evans, C., Whitmore, A., Falloon, P., Smith, P., 2010a. Estimating changes in Scottish soil carbon stocks using ECOSSE. I. Model description and uncertainties. Clim. Res. 45:179-192. https://doi.org/10.3354/ cr00899.

Smith, J., Gottschalk, P., Bellarby, J., Chapman, S., Lilly, A., Towers, W., Bell, J., Coleman, K., Nayak, D., Richards, M., Hillier, J., Flynn, H., Wattenbach, M., Aitkenhead, M., Yeluripati, J., Farmer, J., Milne, R., Thomson, A., Evans, C., Whitmore, A., Falloon, P. Smith, P., 2010b. Estimating changes in Scottish soil carbon stocks using ECOSSE. II. Application. Clim. Res. 45:193-205. https://doi.org/10.3354/cr00902.

Sommers, L.E., Gilmour, C.M., Wildung, R.E., Beck, S.M., 1981. The effect of water potential on decomposition processes in soils. Water Potential Relations in Soil Microbiology. SSSA Specialpubl:pp. 97-117 https://doi.org/10.2136/sssaspecpub9.c3.

Sparling, G.P., Cheshire, M.V., Mundie, C.M., 1982. Effect of barley plants on the decomposition of 14C-labelled soil organic matter. J. Soil Sci. 33:89-100. https://doi.org/ 10.1111/j.1365-2389.1982.tb01750.x.

Tromp-van Meerveld, H.J., McDonnell, J.J., 2006. On the interrelations between topography, soil depth, soil moisture, transpiration rates and species distribution at the hillslope scale. Adv. Water Resour. 29:293-310 (Experimental Hydrology: A Bright Future). https://doi.org/10.1016/j.advwatres.2005.02.016. 